1 - 8. Под этими цифрами мы можем наблюдать боксы, для каждого вида растения. Внешне они могут не отличаться друг от друга, но внутри они кардинально разные. Своя температура, влажность воздуха, способ выращивания, даже примеси входящие в состав полива. Достоинствоэтого способа состоит в том, что это все регулируется автоматически специальной программой, т.е. человеческий фактор нам нужен только для сбора готовой продукции.

9 - В данном месте может находиться блок управление, т.е. мозг всего предприятия. Именно там мы устанавливаем нужные нам параметры под каждый бокс, а так же именно там мы видим неполадки в системах.

10 - Склад - так же зависящий от центра управления.( температура, влажность и др.)

11 - Пространство для передвижения работников

12 - Территория, предназначенная для работающего персонала

Не смотря на примитивность схемы и сжатость информации можно понять, что данное предложение решает нашу проблему. Кроме того, данное предприятие открывает ряд вакансий, что благоприятно действует на экономику территории.

В итоге хотелось бы добавить, что строительство таких комплексов в больших количествах поднимет экономику страны, и позволит совершить импортозамещение экологически чистых продуктов на российских рынках.

\title{
Мякина А.B. \\ Оценка декоративных качеств эустомы крупноцветковой в зависимости от питательной среды
}

РГАУ-МСХА им.К.А.Тимирязева

(Россия, Москва)

doi: 10.18411/lj-30-11-2017-12

idsp: 000001:lj-30-11-2017-12

\section{Аннотация}

Исследовано влияние разных сред на сохранность декоративных свойств и продление сроков реализации срезанной эустомы.

Ключевые слова: декоративные качества, питательная среда, эустома, лизиантус.

Эустома (лат. Eustoma) - род семейства Горечавковых (Gentianaceae). Лизиантус (Eustoma russelianus) или техасский колокольчик, небольшое двухлетнее растение из южной части Америки, как декоративное растение стал популярен в семидесятые годы. Это компактное травянистое растение от 10 до 70 см в высоту, выращиваемое как однолетник, так и двулетник, при холодной зимовке; соцветие метёлка дихазиев. Стебли густооблиственные, листья сизоватые, эллипсовидные, с матовой восковой фактурой. Размер цветка до 8 см в диаметре, на одном растении может образовываться до 20 и более цветков. Цветки колокольчатого вида, немахровые или махровые, самой разнообразной окраски, от голубой до красной, а также белой, также существуют двуцветные и окаймленные.

Большая часть работ о эустоме посвящена агротехнике и экзогенным обработкам для улучшения габитуса. Напротив, мало исследованы проблемы увеличения продолжительности жизни срезки с использованием питательных растворов и физиологические аспекты возрастных изменений в тканях цветка.

Изучение факторов, поиск оптимальной среды и методов, способствующих поддержанию жизненных процессов в срезанных цветках на протяжении всего периода от среза до попадания в руки конечных потребителей, является приоритетной задачей. 
Качество и декоративная ценность цветочной продукции подвержены высоким требованиям, поэтому нужно уметь не только выращивать цветы, но и уметь их хранить. У срезанных цветов отсутствует механизм периода покоя, что значительно усложняет их длительное хранение. Между тем, все обменные процессы продолжаются, но меняют свое направление. Разрушительные процессы начинают доминировать над синтезом органических соединений, из-за чего необходимо создавать условия, замедляющие обменные реакции, или искусственно поддерживать условия, имитирующие нормальный обмен веществ, одновременно предотвращая разложение органических веществ. Целью данного исследования является изучение влияния различных сред на сохранение декоративных свойств и продления срока хранения эустомы крупноцветковой.

\section{Материалы и методы исследования.}

Объектом для проведения исследований являлись срезанные побеги эустомы крупноцветковой сорта Alisa White и четыре питательные среды: вода (контроль), вода с добавлением аскорбиновой кислоты $(0,1$ г/л), вода с добавлением лимонной кислоты $(0,1$ г/л), вода с добавлением препарата Chrysal.

Перед постановкой опыта растения подрезали под острым углом для увеличения всасывающей поверхности и сразу ставили в растворы.

Перед заменой раствора каждые два дня проводили обновление среза.

Срезанные побеги помещали в сосуды (500 мл) с разными питательными растворами. Контролем была обычная водопроводная вода. Опыт проводили в лабораторных условиях при температуре $22^{\circ} \mathrm{C} . .23^{\circ} \mathrm{C}$ и относительной влажности $33 \%$. Продолжительность эксперимента составила около 11 дней.

Действие питательной среды на сохранение срезанных цветков оценивали по изменению декоративных качеств.

Оценку декоративного состояния цветка проводили по 5 балльной системе.

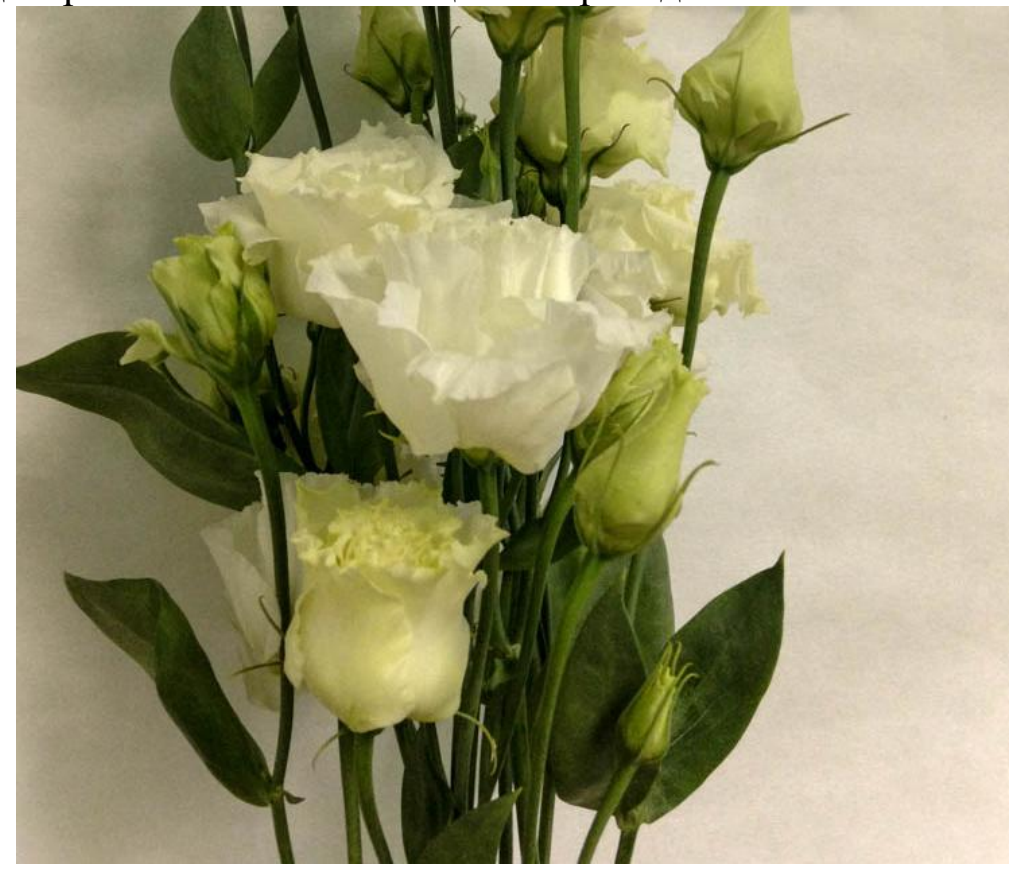

\section{Результаты исследования и их обсуждение.}

Оценку декоративности проводили по оригинальной разработанной методике на основе внешних признаков растения, как по всему растению, так и отдельно по лепестками, тычинкам, стеблю и листьям растения, так как во флористике срезанные цветы используют как полностью, так и некоторые их части при необходимости.

После составления шкалы оценки декоративности растения, был проведен подсчет дней, для сравнения эффективности сохранения жизни срезки в зависимости от препарата. Как видно из рисунка 2, вне зависимости от сезона, самые высокие показатели были отмечены в препарате Chrysal. B контроле вне зависимости от размещения и сорта, показатели немного ниже. В 
зависимости от среды и сезона, реакция цветов была разной: наибольший период при содержании эустомы в лимонной кислоте осенью, самый низкий показатель при содержании растений в аскорбиновой кислоте весной.

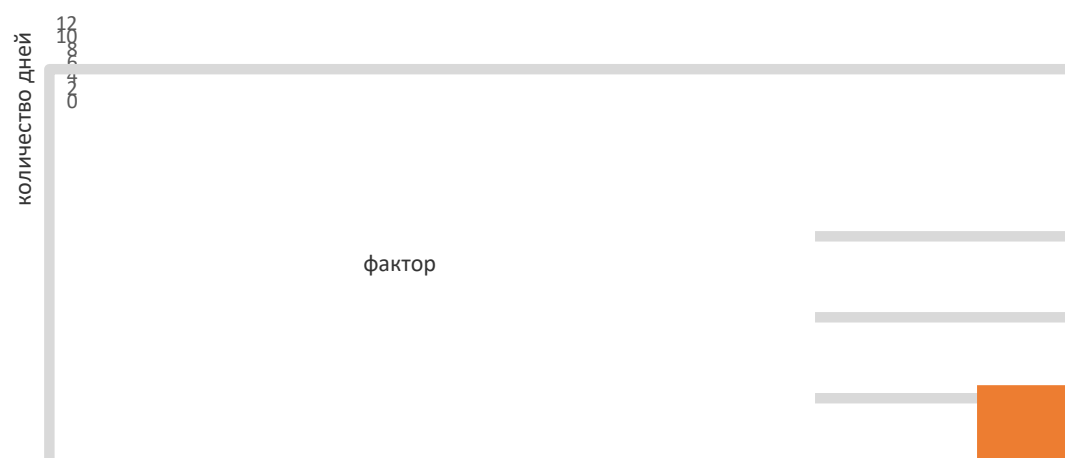

Рис. 2. Количество дней сохранения декоративных качеств срезки эустомы крупноцветковой.

\section{Выводы}

В результате данных исследований выявлено, что сезон закупки цветов не играет существенной роли в продолжительности жизни срезки; при рассмотрении растения в целом, более долгий период обеспечил раствор препарата Chrysal; в среднем, эустома крупноцветковая сохраняет свою декоративность в срезке 8 дней.

$$
* * *
$$

1. Зуев В.В. Горечавковые Сибири [эволюция, филогения]/ АН СССР. Сиб. отд-ние. Центр. Сиб. бот. Сад. - Препр. Новосибирск, 1991

2. Армстронг, Х. Горшечная культура Лизиантуса/ Х. Армстронг-Эксмо, 2004-25c.

3. Колыханова, М.В. Статья «Эустома: Выращивание, уход, размножение»/ М.В. Колыханова-2009

4. Кошкин, Е.А. Физиологические основы качества продукции цветоводства/ Е.А. Кошкин, В.Н. Адрианов, О.Ф. Панфилова, Н.В. Пильщикова - РГАУ-МСХА, 2012-250 с.

5. Игумнов, М.А. Сохранение срезанных цветов: Уч. пособие для кадров массовых профессий / М.А. Игумнов. - М.: Агропромиздат, 1990.-46 с.: ил.

6. Halevy A.H., Kofranek A.M. Evaluation of lisianthus as a new flower crop// Hort Science. 1984. V. 19. №6. Sect. I.P. 845

\section{Степанов А.A. \\ Оценка изменения гидрофобно-гидрофильных свойств гумуса в луговой оподзоленно-глеевой почве при ее использовании для возделывания риса

\author{
МГУ им. М.В.Ломоносова \\ (Россия, Москва)
}

doi: 10.18411/lj-30-11-2017-13

idsp: 000001:lj-30-11-2017-13

Объект исследования. В работе были использованы образцы почвы (таблица 1), отобранные на Сиваковской рисовой системе (Хорольский район Приморского края). Разрезы № 3 и 4 были заложены на рисовых чеках различного времени использования (соответственно, 8 и 15 лет). Разрез № 5, заложенный на пастбище, являлся «контрольным», так как в данном случае почва не подвергалась длительному затоплению.

Содержание работы и методика определения. Характер пространственного распределения и соотношения гидрофобных и гидрофильных участков на поверхности молекул гумусовых веществ (ГВ) определяют их смачиваемость и растворимость в воде, т.е. гидрофобно-гидрофильные свойства. Качество гумуса играет важную роль в процессе агрегации почвы, миграции органического вещества (OB) и др. Если при гумификации 